\title{
Trichobacteriosis: case report and dermoscopic study
}

\author{
Tricobacteriose: relato de caso e estudo dermatoscópico
}

\author{
Marcelo Massaki Guiotoku' \\ Hélio Amante Miot ${ }^{2}$
}

\author{
Paulo Müller Ramos ${ }^{1}$ \\ Silvio Alencar Marques ${ }^{3}$
}

\begin{abstract}
The authors report a case of axillary trichobacteriosis in a 16 year-old patient whose complaints were bromhidrosis and hyperhidrosis axillaris. Although it can be diagnosed clinically, dermoscopy may be useful in some cases and reveal remarkable academic images.

Keywords: Corynebacterium; Dermoscopy; Hyperhidrosis

Resumo: Relata-se um caso de tricobacteriose axilar em paciente de 16 anos de idade cujas queixas eram de bromidrose e hiperidrose axilar. Embora a tricobacteriose possa ser diagnosticada clinicamente, a dermatoscopia pode ser útil em alguns casos e revelar imagens de extremo valor acadêmico. Palavras-chave: Corynebacterium; Dermoscopia; Hiperidrose
\end{abstract}

\section{CASE REPORT}

A 16 year-old male was admitted to the outpatient department reporting excessive sweating in his axillae and unpleasant odor for one year. On physical examination, it was noticed that his axillary hair was surrounded by soft, waxy and yellowish concretions (Figure 1). Dermoscopy images were taken to get close-up details and to improve the diagnosis (Figures 2 and 3). Examination of some hair shafts at optical microscopy by adding $10 \% \mathrm{KOH}$ solution supported the diagnosis of trichobacteriosis. The patient was treated by shaving the axillae and using topical erythromycin $2 \%$. Chlorhexidine was prescribed to prevent relapses.

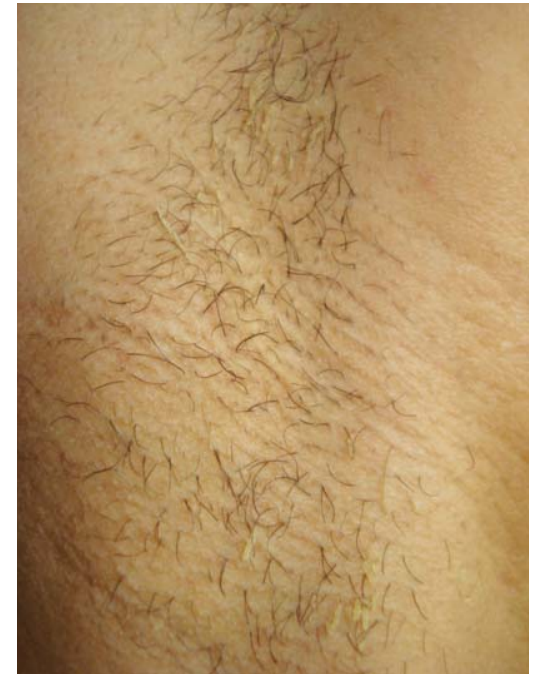

Figure 1:

Trichobacteriosis: case report and dermoscopic study. Soft, waxy and yellowish concretions surrounding axillary hair 


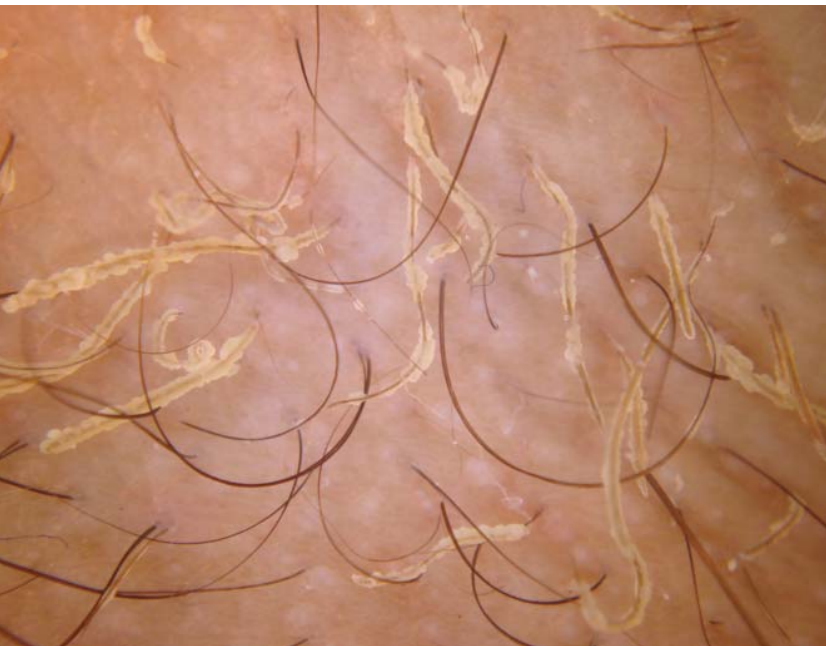

FIgURE 2: Trichobacteriosis: case report and dermoscopic study. Polarized dermoscopy image revealing waxy and yellowish adherent nodules and concretions along the entire length of the hair of the axilla (DermLite ${ }^{\circledast}$ II PRO HR bandlebeld dermoscope, 3Gen, LLC, San Juan Capistrano, California, USA; magnification 10x)

\section{DISCUSSION}

Trichobacteriosis, trichomycosis axillaris or trichomycosis palmellina belongs to the group of cutaneous corynebacteriosis as well as erythrasma and pitted keratolysis. ${ }^{1}$ It is mostly caused by Corynebacterium tenuis and is clinically characterized by yellowish, reddish or blackish sticky concretions surrounding the hair shaft of the axillary or pubic region. 1.5 Hyperhidrosis and improper hygiene are the main predisposing factors. Despite its symptomless condition, treatment may be based on cleansing methods. Sometimes topical antibiotics (erythromycin 2\% or clyndamicin $1 \%$ ) or benzoyl peroxide may be requi-

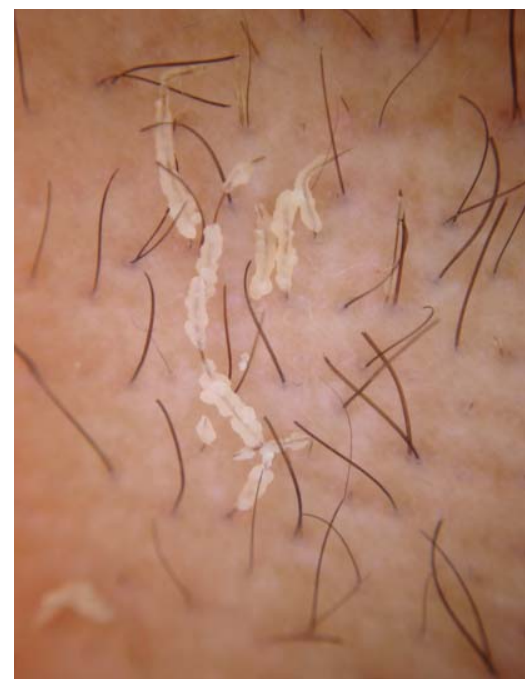

Figure 3:

Trichobacteriosis: case report and dermoscopic study. Close-up picture of polarized dermoscopy revealing a flame-like aspect of pale yellowish adherent nodules and concretions (DermLite ${ }^{\circledast}$ II PRO HR bandleheld dermoscope, 3Gen, LLC, San Juan Capistrano, California, USA; magnification 10x) red. The differential diagnosis includes white piedra, black piedra and hair casts. ${ }^{1-5}$

With the advent of the marketing of polarized dermatoscopes, dermoscopy has increased in popularity among dermatologists worldwide and dermoscopic features of a huge range of dermatoses have been described. ${ }^{6-8}$

Although there is not much challenge in diagnosing trichobacteriosis, we believe that dermoscopy would be a time-saving and helpful tool in doubtful cases.

\section{REFERENCES}

1. Blaise G, Nikkels AF, Hermanns-Lê T, Nikkels-Tassoudji N, Piérard GE Corynebacterium-associated skin infections. Int J Dermatol. 2008;47:884-90.

2. Wilson C, Dawber R. Trichomycosis axillaris: a different view. J Am Acad Dermatol 1989;21:325-6

3. Levit F. Trichomycosis axillaris. J Am Acad Dermatol. 1990;22:858-9

4. White SW, Smith J. Trichomycosis pubis. Arch Dermatol 1979;115:444-5.

5. Freeman RG, McBride ME, Knox JM. Pathogenesis of trichomycosis axillaris. Arch Dermatol. 1969;100:90-5.

6. Duque-Estrada B, Tamler C, Sodre CT, Barcaui CB, Pereira FBC. Dermoscopy patterns of cicatricial alopecia resulting from discoid lupus erythematosus and lichen planopilaris. An Bras Dermatol. 2010;85:179-83.

7. Abraham LS, Torres FN, Azulay-Abulafia L. Dermoscopic clues to distinguish trichotillomania from patchy alopecia areata. An Bras Dermatol. 2010;85:723-6.

8. Abraham LS, Azulay-Abulafia L, Aguiar DP, Torres F, Argenziano G. Dermoscopy features for the diagnosis of furuncular myiasis. An Bras Dermatol. 2011;86:160-2.
MAILING ADDRESS:

Marcelo Massaki Guiotoku

Departamento de Dermatologia, $s / n$

Faculdade de Medicina de Botucatu - UNESP

Campus Universitário de Rubião Jr.

18618-970 Botucatu, SP

E-mail address: marceloguiotoku@yaboo.com.br

How to cite this article: Guiotoku MM, Ramos PM, Miot HA, Marques SA. Trichobacteriosis: case report and dermoscopic study. An Bras Dermatol. 2012;87(2):315-6. 